\title{
研究のスポット
}

\section{プラスチドはざのように形成 されるか?}

\section{電顕で探る植物オルガネラ形成の初期過程}

\section{匂坂勝之助}

北海道大学名裳教授

クロロプラスト(葉緑体)，アミロプラスト（澱粉体あ るいは澱粉形成体), クロモプラスト（色素体）などは, 総称してプラスチド (plastid) と呼ばれる.これらは植 物に特有のオルガネラ（細胞小器官）で, クロロプラス トは光合成，アミロプラストでは光合成された糖から澱 粉粒の合成あるいはこの逆方向の反応による糖類の生成 が行なわれる，植物個体からは，可溶性の同化産物(糖) の固体化 (澱粉粒) によって糖代謝全体の方向性決定に 貢献しているといえるまた，クロモプラストには，植 物種に特有な色素の集積がみられる.ささらに, プラスチ ドの有する特異的な性質の一つとして, アミロプラスト を含も植物組織に光をあてるとクロロフィルの合成が起 こってクロロプラストに変わることが知られている.

このようにプラスチドは, 独立栄養生物 (autotroph) としての植物が光エネルギーを化学エネルギーに変えな がら $\mathrm{CO}_{2}$ から有機化合物を合成する際に基幹的な役割 を担っており,これらの有機化合物, 特に炭水化物に依 存した生命活動を営む人類を含めたすべての從属栄養生 物 (heterotroph) はプラスチドの働きに支えられて生き ているともいえよう、では，このプラスチドは植物体で どのように作られてくるのであろう מ.

\section{プラスチドの増殖}

従来, プラスチドは, 以前から存 在しているプラスチドの分裂によっ てのみ増殖し, 新規な形成 (de novo formation）は起こらないと考光ら れている(1). 細胞の分裂・増殖が起 こる場合には“親”プラスチドの分 裂によって形成された“子”プラス チドが娘細胞に移される。これはプ
ラスチド (生命) の連続性を示す特質である. 分裂は成 熟プラスチドと“プロプラスチド (proplastid)”の両段 階で起こる. オルガネラは, オルガネラ固有の DNA に よる調節を受ける一方で, 細胞核の情報に由来するポり ペプチドを受け取りながら形態と機能を完成させる. 細胞増殖と DNA の複製などについては Kuroiwa ら と Hashimoto ${ }^{(3)}$ の詳細な研究がある.

\section{プラスチドイニシャル}

今から 30 年くらい前, まだプラスチドの遺伝性が確 定されていなかった時期に，Frey-Wyssling と Mühlethaler らは, コケの葉のクロロプラスト中に出芽状態拉 よび分離後とみられる微細構造を見いだした（図 1). 彼らは，これがプラスチド形成の前駆体になる可能性を 想定してプラスチドイニシャル（plastid initial） と呼 び，図 2 に示すような形成経路を提出した(4). ただ，こ の研究が行なわれた頃, 直径が $1 \mu \mathrm{m}$ 以下のオルガネラ を微細構造に基づいて判別することは必ずしも容易でな かった. その後, 電子顕微鏡の性能向上ならびに技術の 進歩を背景にプラスチドイニシャルについて研究が行な

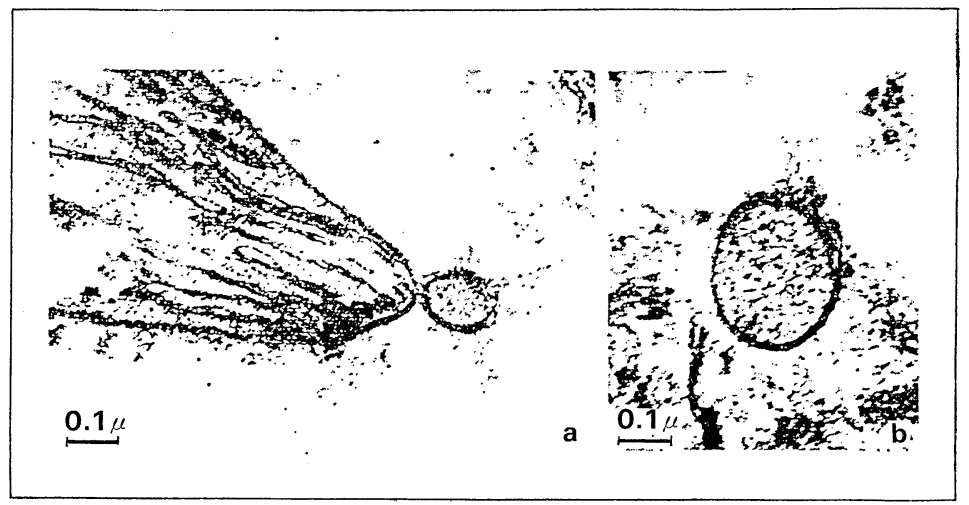

図 1 曰脱分化したコケの葉のクロロプラストに見られる小さな構造体 ${ }^{(4)}$ $\mathrm{a}$ ：出芽状に出ている状態， b : “親”クロロプラストから離れた状態 


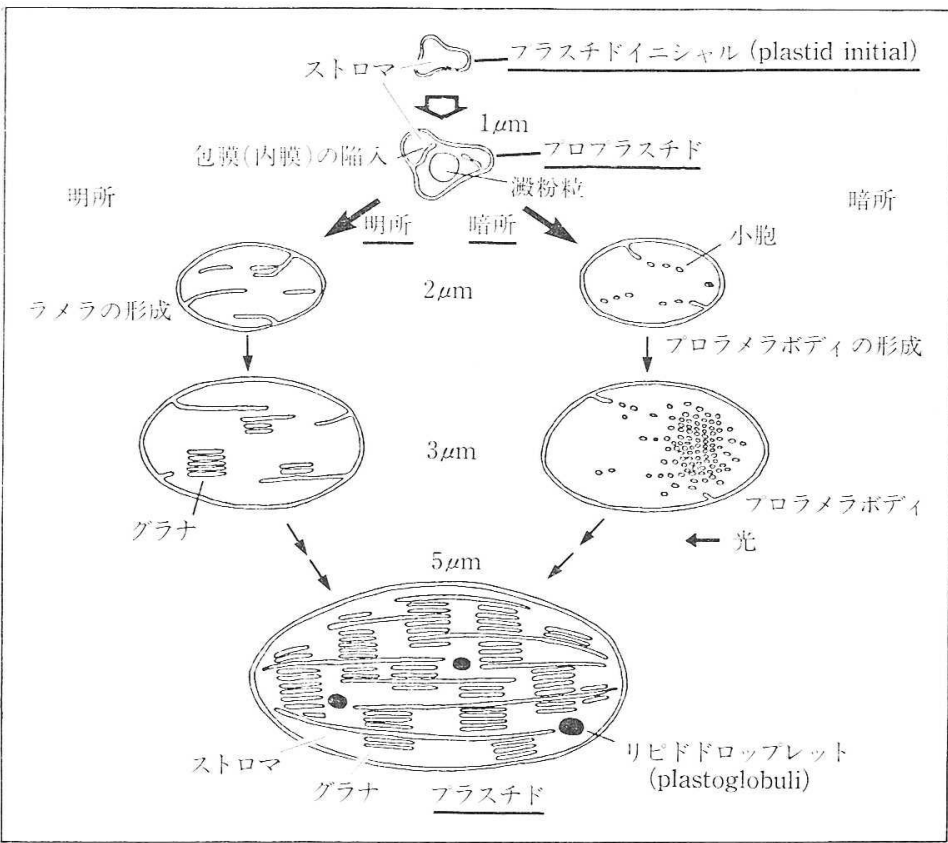

図 2回前駆体としてのプラスチドイニシャルからのプラスチドの形成経路 文献 4)に揭載された経路の一部を略して転載した。

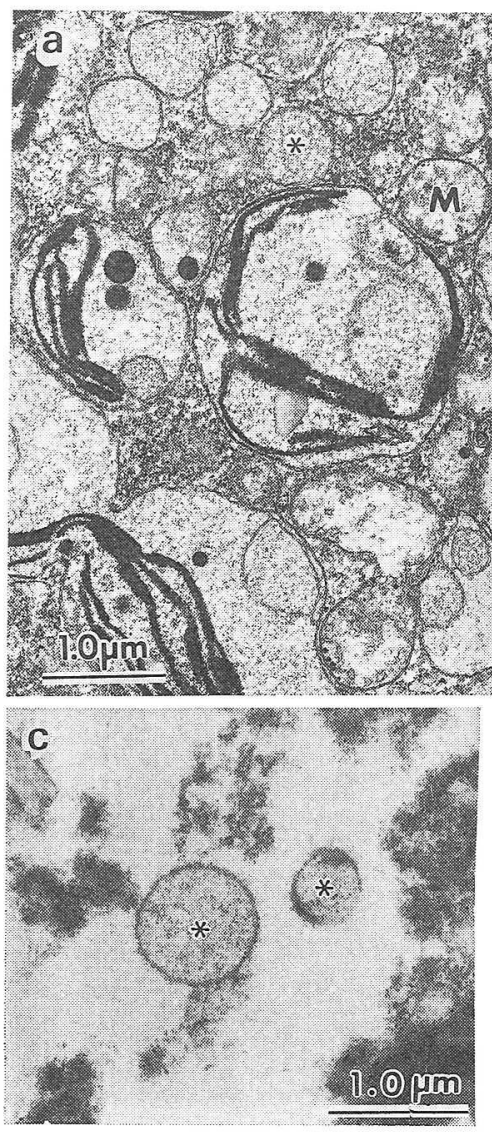

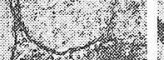
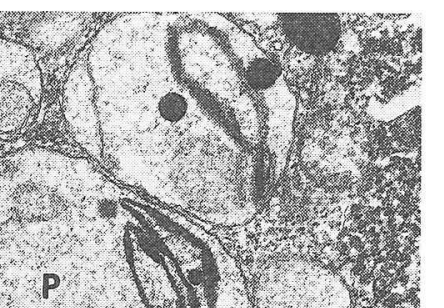

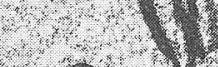
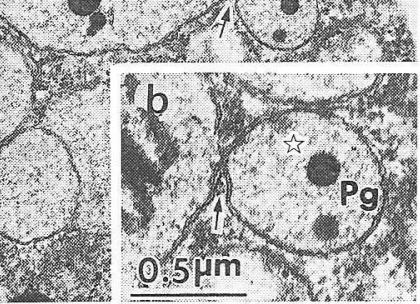

図 3匹ポプラ枝条の皮層柔組織細 胞に存在するプラスチドイニシャ ル $(6,7)$

* : プラスチドイニシャル, M : ミトコ ンドリア， P：プラスチド. 幽：プラ スチドの一部がくびれて出芽状態を 呈している。矢印は“親” プラスチド （P）にくびれができた個所（a），b： a の々の部分を拡大したもの. Pg : プ ラストグロブリ。c：a と同じ材料の 細胞壁を酵素的に溶解してから遠心分 離したプラスチドイニシャル（（＼cjkstart印).
われた結果，実験結果を再現できな からたことから，1980 年代前半に $2 つ の$ 総説の中でその存在が否定さ れることとなった らないが，出現頻度の低いオルガネ ラであったこれらを電頙的に捉える ことが難しかったと手考えられる。 とにかく，この時点で Frey-Wyssling と Mühlethaler らのプラスチ ドイニシャルの存在は否定されたの である。

ところが 1991 年になって,プラ スチドに“くびれ”ができて出芽に 似た状態㐨よびこれが遊離したと思 われる微細構造が木本類で見いださ れた(6).この未同定の“構造体”は， その微細構造が F r rey-Wyssling · と Mühlethaler らのブラスチドイニシ ャルに類似していることから，暫定 的に同じ名前が用いられている。

\section{プラスチドイニシャルの形態}

図 3-aの*印はポプラの皮層部采 組織細胞に出現するプラスチドイニ シャル（PI と略す）である。幻印の 部分を抆大したものが図 3-bで， プラスチド（アミロプラスト）の一 部分に“くびれ”ができたのち，両 方のエンベロープ膜（包膜）が一点 でつながっている微細構造を示して いる. PI は（親）プラスチドの極 く周辺に集塊状態で存在している (a) がここはbのような形態を 経て PI の形成が続くことによるも のと思われる。

PI の形成が活発な時期には，(親) プラスチドのストロマ (stroma) 内 そェンベロープ膜と同じ微細構造の 膜系の生成がみられる場合之既存の エンベロープ膜が部分的に消隇しな がらプラスチドイニシャル様の構造 


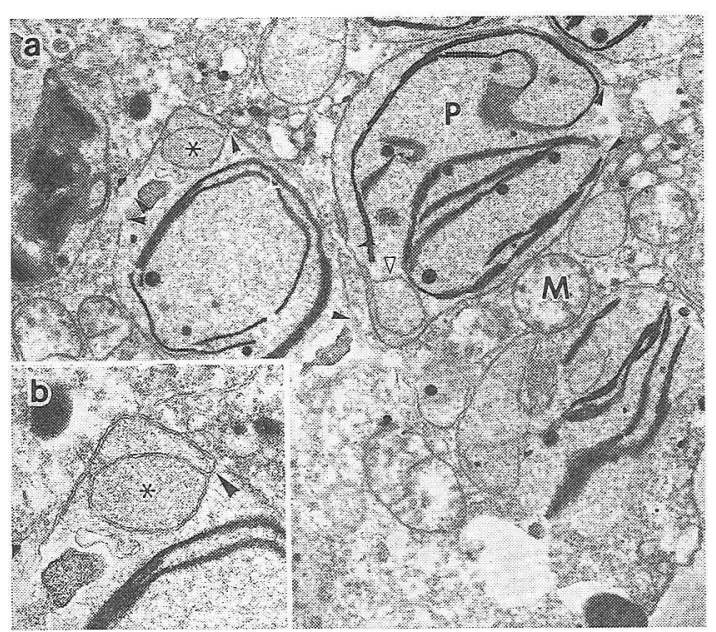

図 4 回休眠解除後 (真冬) に皮層部柔組織の細胞に出現 するプラスチド

エソベロープ膜の消失個所 (黑い矢印)，プラスチド内にェンベ ロープ膜状の膜構造（ $\triangle$ 印）括よびェンべロープ膜とつながっ ているプラスチドイニシャル様の構造体（*)が見える．M：ミ トコンドリア， P：プラスチド. a : × 12,000. b : a の*部 分を拡大したもの $(\times 22,000)^{(7)}$.

体を形成する場合がしばしば観察される（図 4-a， b）. 後者の微細構造を経る PI 形成機構が動いている可能性 については検討がまったく進んでいないのでここでは 前者について述ベる。

In vivo の試料で撮れる PI のエンベロープ膜は, プ ラスチドのエンベロープ膜と同様に二重膜構造（図 3b)である.PI の内部はストロマ部分のみの電顕像を
示す場合が多いが，植物によってはプラストグロブリ (plastoglobuli, oil droplet) が高頻度で出現するので， ミトコンドリアとは容易に判別することができる。ポプ ラの PI 内にはチラコイド膜はまったく見当らない(図 3-b) が，リンゴの木ではこれを有するものが多く見ら れる、また，あたかもェンベロープ膜が循入したかのよ らに見える小胞が通常存在している. 一方，ポプラの皮 層部柔組織細胞の細胞壁を酵素で溶解して分離した PI 画分の電曊写真 (図 $3-c)^{(8)}$ を見ると, in vivo と in vitro の微細構造は一致しているとみることができる. なお，分離したプラスチド（およびェンベロープ膜）は ${ }_{i}$ n vivo のような微細構造を与えないので，出版物中に 見いだすのは困難である.

\section{プラスチドイニシャルの形成時期}

PI の形成亡存在を確認できるのは，木本植物では休 眠覚醒後の $2 \sim 3$ 力月間である. 北海道・東北地方括よ び高山に生育している木本植物は，8月中下旬から 9 月 上中的末でに休眠（自発的）に入って，翌年の 1 月上中 旬頃までこの状態に保たれる，1月下旬は年間の最低平 均気温を示声時期である（札坭で $-9.2^{\circ} \mathrm{C}$ ). 植物は 1 月 中旬頃には休眠から覚めるが，環境温度が生育にまった く不適なので, 強制的休眠の状態を 3 月下旬から 4 月上 旬まで保ち，その後気温が高まって生育が可能になると 開芽・伸長を始める，この間，ポプラの皮層部柔組織細

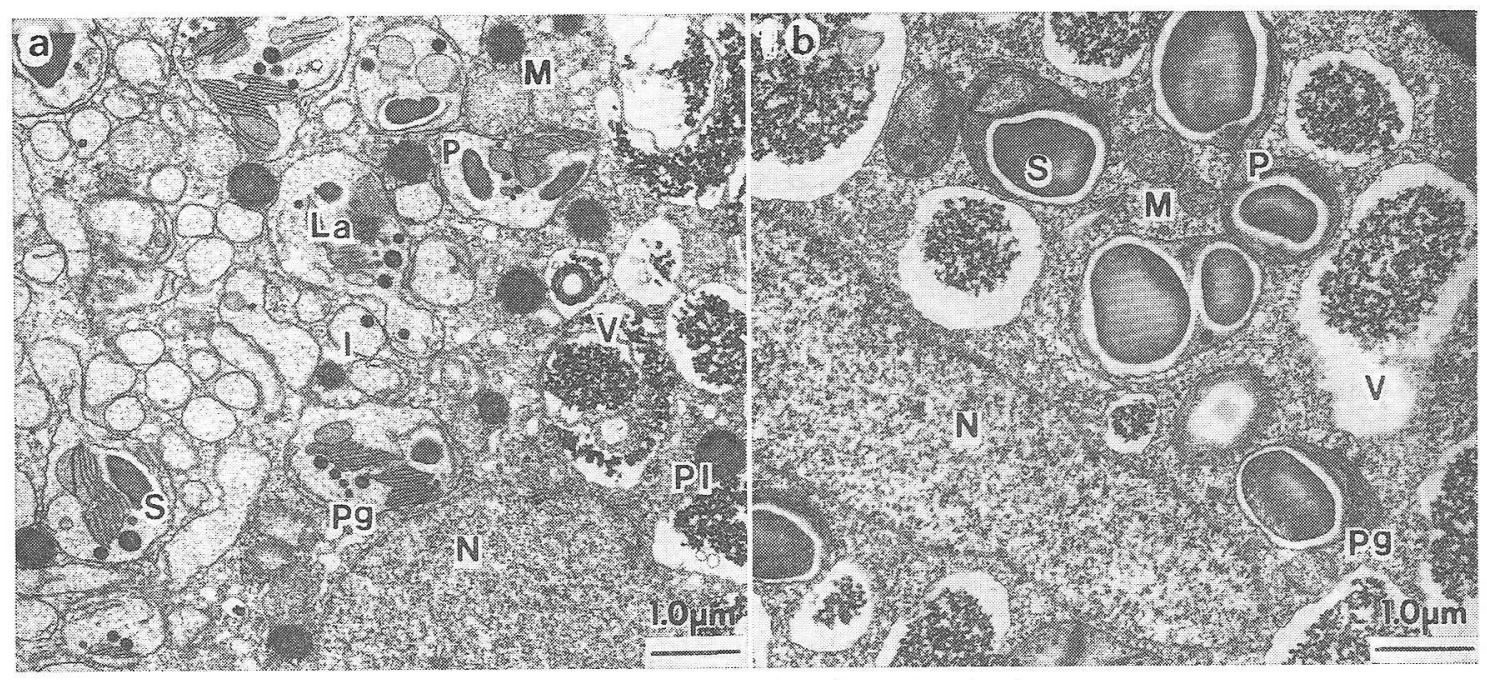

図 5 回戸外越冬 (a) と室内越冬ポプラ (b) の冬芽細胞におけるプラスチドイニシャル

暖かい室内で越冬させるるプラスチドイニシャルの形成が見られない. I ：プラスチドイニシャル，La：プロラメラボディ，M：ミ

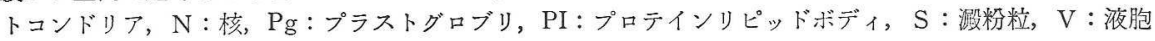


胞と葉芽では，1月中旬から 3 月下旬までプラスチドか ら“くびれ状態”を経て PI の形成が続く。これは毎年 繰り返される. 草本植物については後述する.

\section{低温環境による休眠覚醒とプラスチドイニシャル の形成}

低温環境下の生活が生活環に組み込まれている植物で は低温度に対する要求性があるので，暖かい室内で越冬 させると冬芽の代謝は不順で, 春が来ても開芽・伸長が みられないことが知られている。 そこで, 室内越冬と戸 外越冬の 2 組のポプラの冬芽について, 秋から翌春まで 細胞の微細構造の变化を続けて調査して, 形態的に PI 形成の有無を検索してみた。図 5-a, b はと代表的な電顕写真であ る(9). 戸外で越冬しつつある冬芽の 細胞（a）には集塊状の PI が豊富 に見られまたプラスチドは通常の (成熟)プラスチドとは異なる微細構 造をもっていてプロラメラボディあ るいはラィラをもつ発達中の形態を 示している. PI の内部は未発達で, コ チラコイド膜の発達は泀とんど見ら れない.PI および発達中のプラス チドにはプラストグロブリを有する ものが多数見られる。

一方, 室内越冬の冬芽では, PI の 形成はまったく認められない（b). 戸外で越冬している冬芽の細胞では プラスチド内の殷粉粒が消失して糖 類に变わるが, 室内越冬の冬芽細胞 の澱粉粒は秋に蓄積したときに比べ てあまり変化を示していない。この ことは, プラスチド自体の性質の变 化が低温度によって起こることを示 唆しており,その一連の生理的変化 の過程に PI の形成反応が組及込ま れているものと思われる，換言する と,この試料ではプロラメラボディ やラメラのような構造体をもつ若い プラスチドも見当らないので, PI は プラスチド代謝, 特にプラスチドの
新生の際に形成されるものと考えられる。

\section{プラスチドイニシャル形成の一般性}

PI がプラスチド新生の初期段階に形成される前駆体 であれば，ての形成については一般性があるはずであ る. 事実, ポプラ以外にも，調查した次のようなすべて の植物細胞に PI が見いだされている(10). ダケカンバ (アジア北部の高山)，オオヤマザクラ（東北・北海道扮 よび泠温帯)，ウンリニウ柳（東シベリア），エゾニワト コ(ウスリー川付近から北海道)，果樹園で栽培されて いるリンゴやグスベリなど，それぞれ形成される時期は ポプラと同様に真冬である.

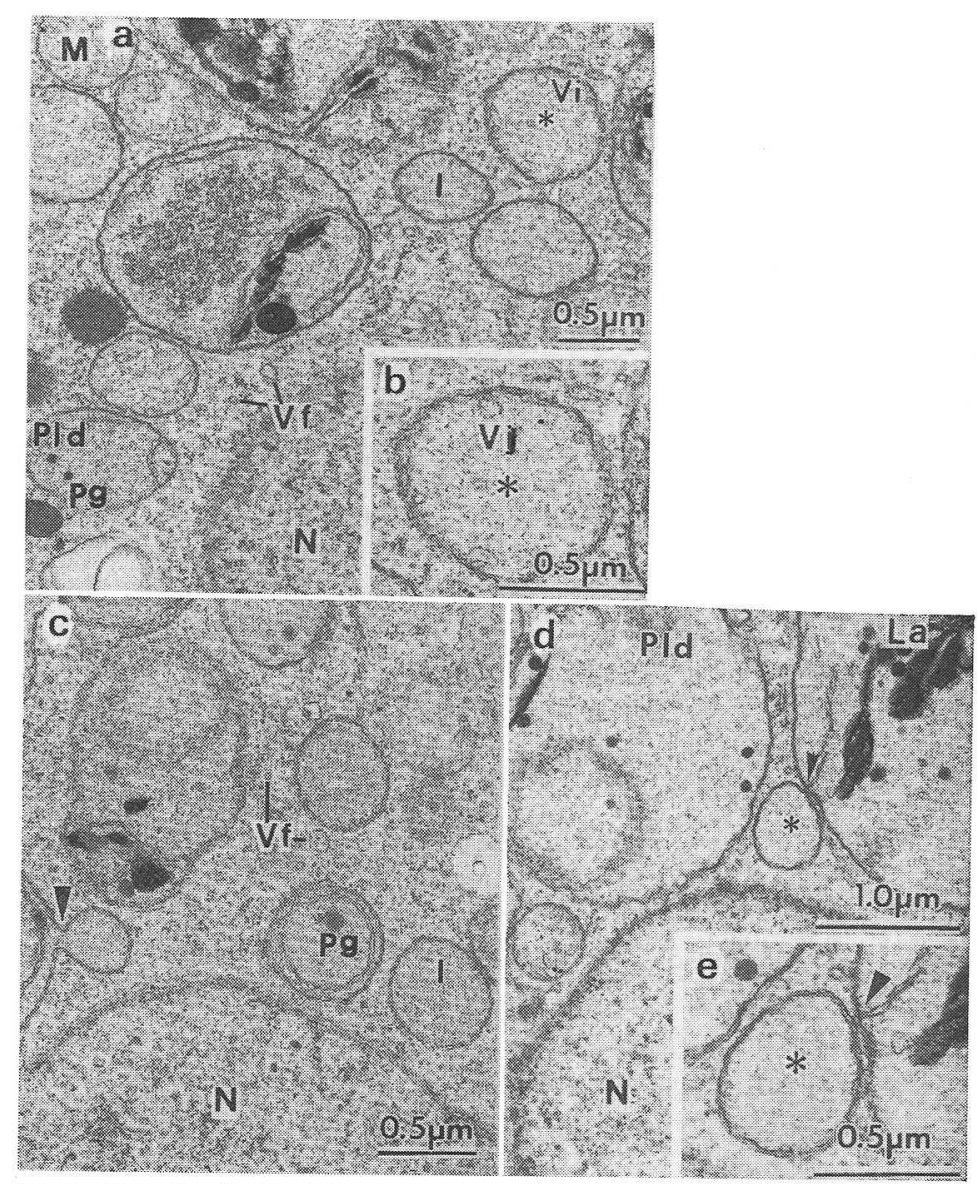

図 6四リンゴの葉芽, 花芽および皮層部柔組織の細胞に見られるプラスチド イニシャルの形成

a ：葉芽の細胞. b : a の*を拡大したもの. c : 花芽の細胞. プラスチドにくびれが できている(三角失印). $\mathrm{d}$ : 皮層部の細胞. エンベロープ膜でつながっているが分離寸 前の構造体 $(*)$ が見党る. e ：dの*を拡大したもの. I ：プラスチドイニシャル， $\mathrm{La}$ : プロラメラボディ, $\mathrm{M}$ ：ミトコンドリア, $\mathrm{N}$ ：核, Pg : プラストグロブリ, Pld : 発達中のプラスチドイニシャル，Vi：プラスチドイニシャル中の小胞，Vf : チトゾー ルの小胞 


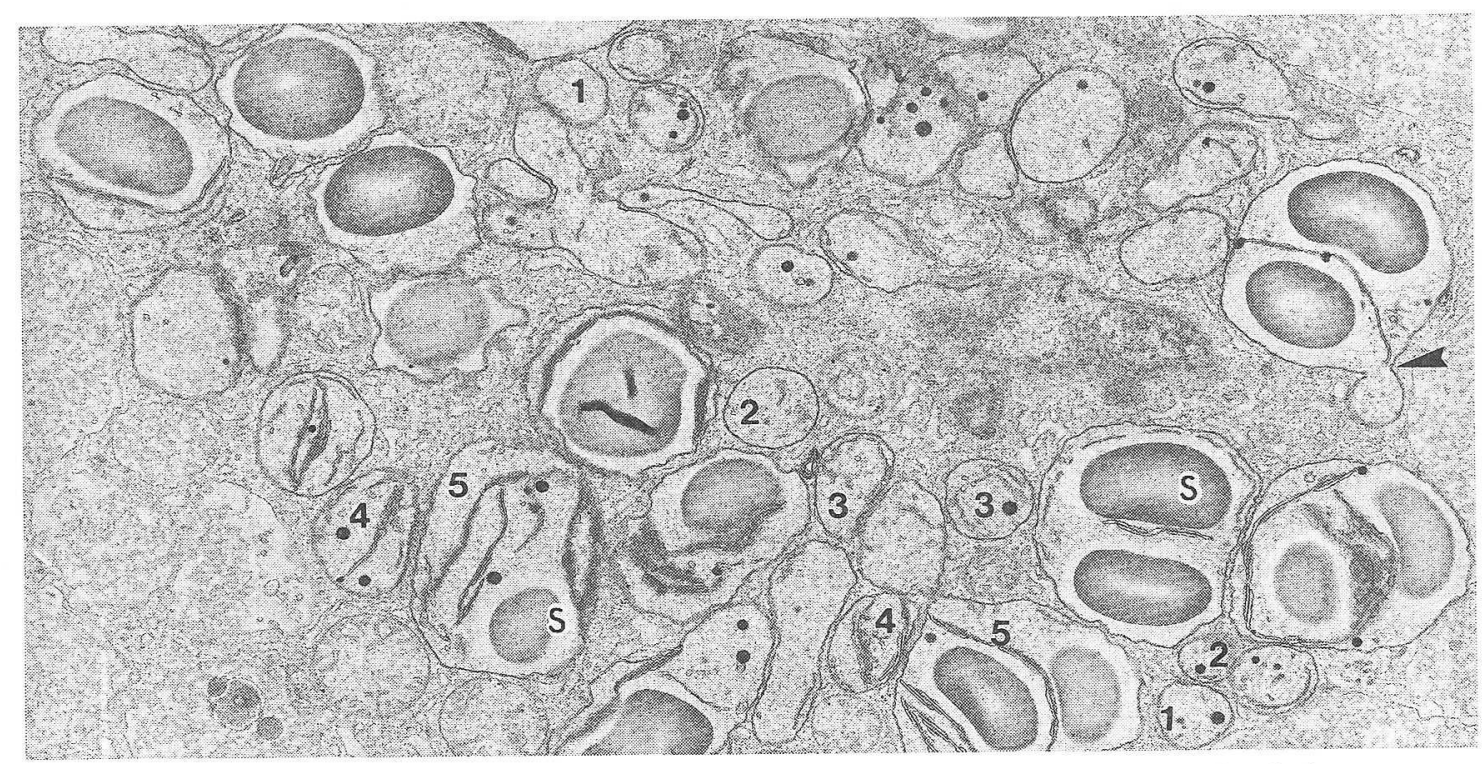

図 7 回プラスチドイニシャルから成熟プラスチドを形成する発達過程を示唆している微細構造（ポプラ）

1 番はプラスチドイニシャル，5番は成熟プラスチドを表わしている．プラスチドイニシャルを形成する段階の構造（三角印）から

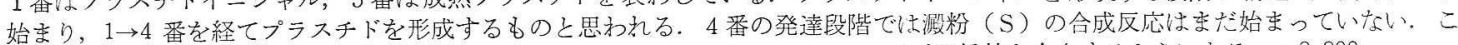
の微細溝造は 3 月下旬の試料で得たもので，4 月上旬になるとすべてのプラスチドが澱粉粒を含有するようになる. $\times 8,800$

\section{プラスチドイニシャルを形成す} る組織機能のコーディネーショ

植物が生育の体制を変えるときに は,すべての組織について変化とた ルガネラの形成などとがタイミング を合せて起こるように調整されてい ると思わ秃る，実際に，リンゴの木 の葉芽, 花芽扣よび皮層部柔組織細 胞について調べると，図 6-cに見ら れるように花芽の細胞の核周辺に PI そ“くびれ”のでき始めた（親） プラスチドが観察された。同じよう な微細構造が葉芽の細胞 (a) と皮 層部柔組織細胞 $(d)$ でも認められ

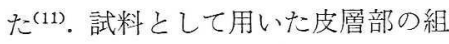
織は形成層に近い部分から採ってい るので，形成層飞执いても PI の形 成が進えでいることが期待できる. このような各組織の細胞が示寸電顕 写真から，(親) プラスチドから PI の形成は一植物個体の寸べての組織

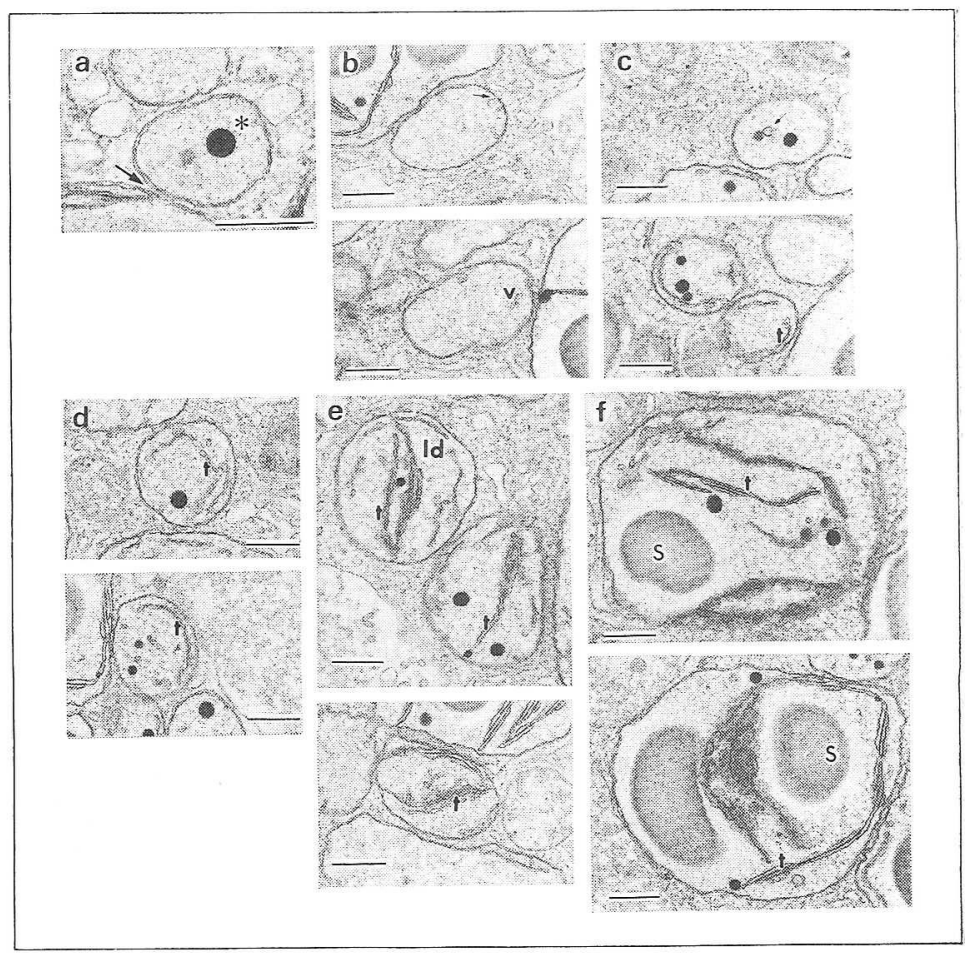

図 8 日プラスチドイニシャルを前駆体としてプラスチドを形成する経路 $1 つ の$ 細胞像から類似した形態を2つずつ取り出して示してある. * : プラストグロ ブリ, $\mathrm{Id}$ : 発達中のプラスチドイニシャル, $\mathrm{t}$ : チラコイド膜, $\mathrm{v} ：$ 小胞. バー $: 0.5$ $\mu \mathrm{m}$. 
に含まれる細胞中で一斉に始まり，開芽・伸長の始まる およそ1か月前に終わるものと考光られる。

\section{プラスチドイニシャルの分離}

ポプラの皮層部柔組織細胞の細胞壁を酵素で溶解して 無細胞抽出液を調製し，これを遠心分画して in vivo $\mathrm{PI}$ と同じ微細構造のオルガネラを得ることができる (図 3-c) ${ }^{(8)}$. この画分にミトコンドリアの混在は見られ ない(PIはミトコンドリアと同程度の大きさなので， トコンドリアの画分に混在している場合がある). ミト コンドリアと異なって PI はひだ状の構造 (クリステ) がなく，ストロマのみの微細構造を示す．并の他の形態

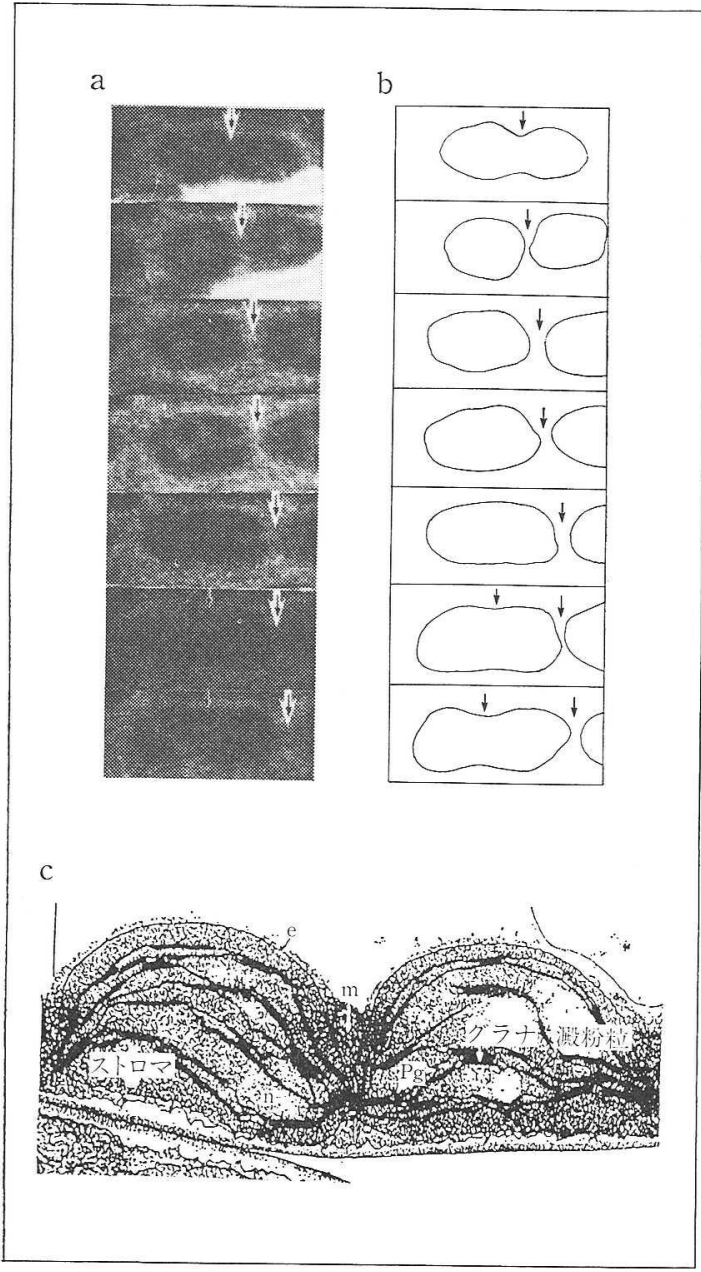

\section{図19日等分裂によるプラスチドの増殖}

ニテラのクロロプラストが分裂する過程を連続撮影したもの (12) ( a : 矢印の個所で分裂する). b : aのクロロプラストをアウ トラインで示したもの, c : 等分裂の最終段階(1). e : envelope 膜, $\mathrm{m}$ ：ミトコンドリア, $\mathrm{n}: \mathrm{DNA}$ 核様体, $\mathrm{Pg}$ : プラストグ ロブリ、くびれの形成部位にミトコンドリアが見える.
的な特徵は上記の in vivo PI と同様である. したがの て，これまでに得られた知見を総合すると，PI は細胞 内に単体で遊離して存在していると結論できる.

\section{プラスチドイニシャルからプラスチドの形成}

PI が発達しながらプロラメラボディあるいはラィラ 構造をるつ中間体を経て “成熟” プラスチドとなる過程 はまだ証明されていない，微細構造を見るときの電顕 試料は固定してしまうので, 細胞内の変化過程を連続し て観察できないからである. PI はミトコンドリアくら いの大きさ (1 $\mu \mathrm{m}$ あるいはこれ以下) なので, この形成 と初期の発達過程の微細構造を連続撮影した成果は未だ 得られていない，PI からプラスチドを形成する場合に 期待される発達過程の全体像を細胞の微細構造の中から 見つけて概観するにとどまっている. 図7はPI の形成 が進んでいる“くびれ”の構造を加えると6 種の(中間 体の）微細構造が見られる. in vivoに和けるPI の発 達過程の全体像を示するのである(10).この図と他の結果 も合わせると，図８亿示すような過程を経てプラスチド が形成されるものと考它られる(8).

\section{これまで主に研究されてきたプラスチド形成系}

草本植物を用いた研究で，栄養細胞が增兄るときは (成熟)プラスチドの等分裂によるプラスチド数の增加が 起こり,一方分裂組織 (茎頂, 根の先端, 形成層) では プロプラスチドの分裂によってプラスチドが増加すると 考光られている(1,5). しかし，プラスチドの等分裂は成 長していない時期（休眠中，12 月）にも起こっている ことを示吉電䫓写真も得られている( ${ }^{(6)}$. 等分裂によるプ ラスチドの增殖を明瞭に示した成績の一つとして，ニテ ラ (Nitella) クロロプラストなどの分裂過程を連続的に 撮影した研究がある（図 9-a) (1,12)。また，図 9-c 惊 等植物のクロロプラストが等分裂によって増殖している 最終段階の微細構造である(1).

一方, 分裂組織に多数存在するプロプラスチドは図 10 のような微細構造をもっている(ソラマメの根端)(13).

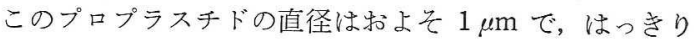
と2 層に見えるェンベロープ膜, 多数の小胞, 小さな澱 粉粒, 拈よび若干量のチラコイド膜を有するが，ストロ マの膜系は未発達である.プロプラスチドの大きさ・形 状は植物種や組織によって違いがみられる。また，同一 


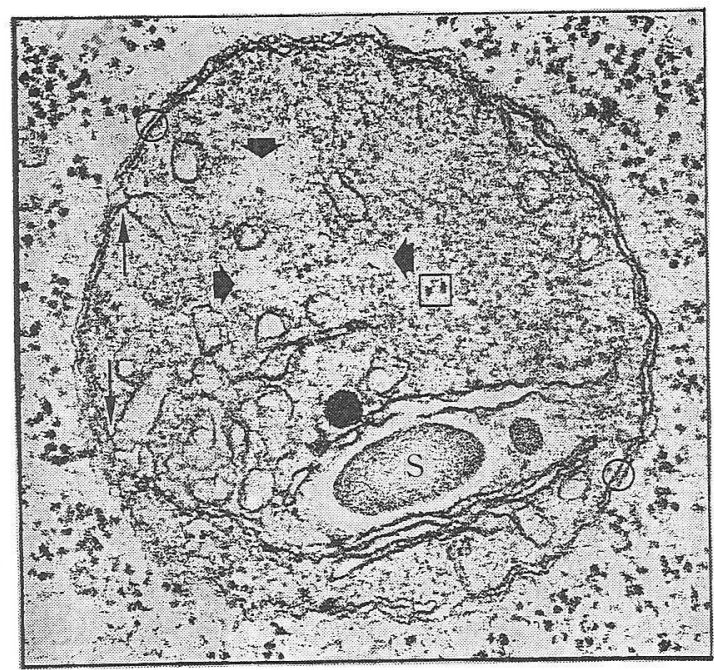

図110匹プロプラスチドの典型的な微細構造(ソラマメの 根の先端) $)^{(13)}$

○：エンベロープ莫は二重膜である，矢印のところで内側の膜 と小胞がつながっている. $\mathrm{S}$ : 洪粉粒，大きな矢印：DNAの分 布域と推定される個所， $\square$ :この中に見られる粒子はリボソー 么 (推定). $\times 77,000$

の分裂組織であっても，大きさが同じで微細構造の異な る“プロプラスチド群”——たとえば港粉粒の有無— が存在するが, 従来, これらの構造体を一括してプロプ ラスチドと呼んでいる.

最近, 微細構造の異なるプロプラスチド群は相互に機 能的にも大きな違いのあることが免疫電子顕微鏡法で明 らかにされだ(18).プロプラスチドとこれが発達したプラ

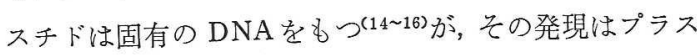
チドの種類（アミロプラスト，クロロプラストなど）と 発達段階による制御を受けている(17)。たとえば，アミロ プラストの役割は澱粉粒の蓄積であるが, 澱粉合成反応 を触媒する酵素の 1 つ結合型澱粉合成酵素はすべての “プロプラスチド”に必ずしも存在しない(18) (図 11).つ まり，この酵素（扣よび他の蛋白質）がまだ発現されて いないオルガネラ成分が幾つか含まれている，発達段階 が異なり機能に違いのあるオルガネラを分けて命名する 必要があるように考允られる。

さらに, 高等植物の分裂組織で, 大きな親プラスチド から小さい“プロプラスチド”が生ま机てくることを示 す微細構造—プラスチド（生命）の連続性、すなわち “親”プラスチドから“子”プラスチドへ DNA が分与 された初期の形態——はまだ観察されていない.このこ とに関連して, プラスチドの発達を記述した総説中に,

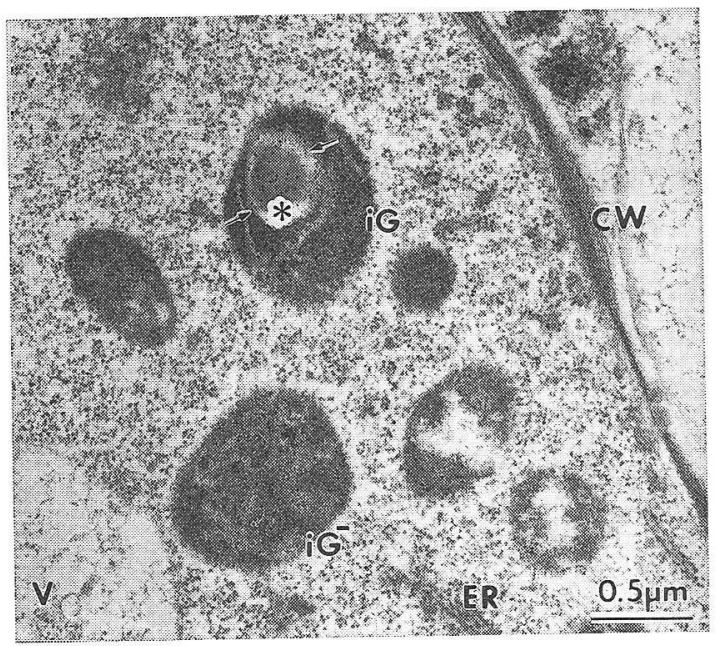

図 11 圆 ジャガイモのストロン（匍匐枝）に存在するプロ プラスチド

大きさが同じであっても結合型浿粉合成酵素を含有するものと 持たないグループに分けることができる．図は免疫電顕で調べ た結果で，抗原抗体反応が陽性なオルガネラ部位（酥素の存在 する部位) は金コロイド粒子（矢印）の有無で検出される。*： 㳊粉粒, $\mathrm{iG}: \mathrm{IgG}$ 反応が晹性のオルガネラ, $\mathrm{iG}^{-}: \mathrm{IgG}$ 反応が 陰性のオルガネラ, $\mathrm{CW}$ : 細胞壁, $\mathrm{ER}$ : 小胞体, $\mathrm{V}$ : 液胞.

相互に変換するモデル経路が提出されている(19).すなわ ち，変形した形態をとっているプラスチド(アメボイド プラスチド; amoeboid plastid), アミロプラスト，およ びプラスチド内が未発達で小型のプラスチド（エオプラ スト ; eoplast) の3群をプロプラスチド段階にあるグル 一プそみなし，相互に転換するものとしている．実際に 分裂組織の細胞を検索してみると，時としてアメボイド プラスチドが見いだされ(20,21)，分裂の初期と推定され る形態が認められるが, “子”プロプラスチドを与をる 部位にはすでに結合型澱粉合成酵素が分布しているの で(18)，前述のようにこの酵素を欠くプロプラスチドの形 成過程を説明することができないまたた, 細胞内にアメ ボイドプラスチドを見いだせない場合が多い。さらに， 前記のオルガネラ群はサイズが異なるので, アメボイド プラスチドを経ない相互転換の場合には，サイズが変わ る機構を同時に示すことが望まれる. 分裂組織以外にア メボイドプラスチドは培養細胞にも存在している(21).

\section{プラスチド前駆体としてのプラチドイニシャル， エオプラストならびにプロプラスチド}

“エオプラスト”と呼ばれたオルガネラは，今日的な 分類ではプロプラスチド群に属するものと考学られる。 
また, 遺伝子の発現レベルに関する研究は行なわれてい ない. プロプラスチド群は前述のように, 発達段階の異 なる（少なくとも） 2 成分から成るが，その中のより若 いプロプラスチドとプラスチドイニシャルは, 微細構造 からみて同一グループに入るオルガネラである可能性が ある.これまで述べてきたよらに，プラスチドイニシャ ルが新規なオルガネラであること，またとの形成機構と 微細構造が明らかにされた. 関連して, 分裂組織でプロ プラスチドあるいはプラスチドイニシャルが形成される 過程の解析と，この過程で “親” プラスチドに存在する 澱粉合成酵素などがいったん消去される機構の解明が魅 力的な研究課題の一つになった.

\section{文献}

1) J. V. Possingham \& M. E. Lawrence : Int. Rev. Cytol., 84, 1 (1983).

2) T. Kuroiwa, T.Suzuki, K. Ogawa \& S. Kawano: Plant Cell Physiol., 22, 381 (1981).

3) H. Hashimoto: Protoplasma, 127, 119 (1985).

4) A.Frey-Wyssling \& K. Mühlethaler : "Ultrastructure
Plant Cytology", Elsevier, Amsterdam, 1965.

5) J. V.Possingham: Annu. Rev. Plant Physiol., 31, 113 (1980).

6) S. Sagisaka \& H. Kuroda : Agric. Biol. Chem., 55, 1671 (1991).

7) S. Sagisaka : Trees, 5, 143 (1991).

8) S. Sagisaka : Biosci. Biotech. Biochem., 58, 1527 (1994).

9) S. Sagisaka : Plant Physiol., 99, 1657 (1992).

10) S. Sagisaka : Trees, 8, 93 (1993).

11) S. Sagisaka : Biosci. Biotech. Biochem., 57, 1641 (1993).

12) P. B. Green : Am. J. Bot., 51, 334 (1964).

13) B.E.S. Grunning \& M.W. Steer : "Ultrastructure and the Biology of Plant Cells", Edward Arnold, London, 1975.

14) B. G. T. Pogo \& A. O. Pogo: J. Cell Biol., 22, 296 (1964).

15) P.E. Highfield \& R. J. Ellis : Nature, 271, 420 (1978).

16) T. Kuroiwa \& T. Suzuki : Exp. Cell Res., 134, 457 (1981).

17) D. Macherel, H. Kobayashi, E. Valle \& T.Akazawa : FEBS Lett., 201, 315 (1986).

18) S. Sagisaka : Biosci. Biotech. Biochem., in press.

19) W.W.Thomson \& J.M. Whatley: Annu. Rev. Plant Physiol., 31, 375 (1980).

20) S. Sagisaka : Biosci. Biotech. Biochem., 58, 1077 (1994).

21）匂坂勝之助 : 未発表.

22) S. Sagisaka : Biosci. Biotech. Biochem., 58, 1153 (1994).
お知らせ

\section{平成 7 年度日本応用糖質科学会 東日本支部シンポジウム “多糖の知られざる機能”}

日 時: 平成 7 年 7 月 7 日（金） $10: 00 \sim 16: 30$ (9:40開場) 場 所: 共立女子大学共立講堂 (東京都干代田区一ツ橋 2-2-1) 主 催 : 日本応用糖質科学会東日本支部 (参加費 : 3000円) プログラム：

(1)多糖類による食品物性形成・浅井以和夫（三栄源エフ・エ フ・アイ(株)）／(2)食物物性と啮むこと・・斉藤 滋（神奈川 歯科大) /(3)高齢者食と多糖・川端晶子 (東京農大) /(4)食品 の执いしさの評価・畑本二美 (雪印乳業(株))／(5)多糖類の 化粧品への応用・松田 伯 ((株)資生堂)

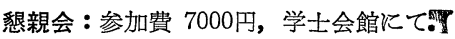

問合せ : 日本応用糖質科学会東日本支部事務局 王子コーンスターチ(株) 第一営業部 吹野弘武 中央区銀座 1-7-10 Tel. 03-3563-3464
お知らせ

$$
\text { ミニシンポジウム }
$$

\section{“生体高分子の働きと柔らかさ”}

日 時: 平成 7 年 7 月 1 日（土） $10: 15 \sim 14: 10$

場 所: 大阪府立大学学術交流会館 干593 大阪府堺市学園町 1-1 Tel. 0722-52-1161

主 催 : 日本農芸化学会関西支部

プログラム：(1)触媒作用と分子の動き・X線結晶解析からのア プローチ・加藤博章 (京大化研) /(2) NMR から見た生体高 分子の運動性・西村重德 (阪府大農) /(3)圧縮率”から見た蛋 白質分子の柔らかさ・月向邦彦 (広大理) /(4)新規な゙複合糖 質の合成之機能解析:-竹川 薰 (香川大農)

参加費 : 無料

連絡先 : $\mathbf{T} 593$ 大阪府堺市学園町 1-1 大阪府立大学応用生物化学科 Tel. 0722-52-1161 ex. 2462

引き続いて日本農芸化学会関西支部例会第 390 回例会一般講 演が行なわれます。すた, 例会終了後, 同会館にて懇親会（会 費 4,000円）を予定しております．多数ご参加ください。 